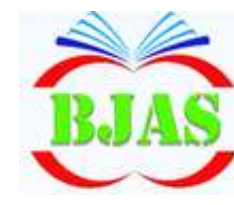

ISSN $1814-5868$
Available online at http://bjas.bajas.edu.iq

https://doi.org/10.37077/25200860.2021.34.2.15

College of Agriculture, University of Basrah

Basrah J. Agric. Sci., 34(2), 195-203, 2021
Basrah Journal

of Agricultural

Sciences

E-ISSN: 2520-0860

\title{
Biochemical Assessment of Peas Pisum sativum Varieties
}

\author{
Viliana Vasileva* \& Valentin Kosev ${ }^{1}$
}

Institute of Forage Crops, 89 “General Vladimir Vazov” Str., 5800 Pleven, Bulgaria

*Corresponding author e-mail: viliana.vasileva@gmail.com; ${ }^{1}$ valkosev@ hotmail.com

Received 24 February 2021; Accepted 11 July 2021; Available online 4 November 2021

\begin{abstract}
Seven peas (Pisum sativum L.) varieties different originated, i.e, X07P54, X06PWY, NDPO80138-B-2, CA1P, L020140, Wt6803 and Mir were studied. Biochemical assessment of fresh aboveground biomass and seeds of peas varieties were done. At the beginning of flowering stage the NDPO80138-B-2 and X07P54 were reported high levels for crude protein $(22.33 \%$ and $21.87 \%)$, crude fibre (25.94\% and $25.76 \%)$ and crude ash $(10.39 \%$ and $9.47 \%)$. In technical maturity with high crude protein and crude fibre contents NDPO80138-B-2 (21.59\% and 21.38\%), X06PWY (19.95\% and 21.36\%), X07P54 (19.78\% and 20.57\%) and CA1P (19.60\% and $22.53 \%$ ) were distinguished; by calcium CA1P (2.09\%), and by phosphorus Wt6803 $(0.54 \%)$. More significant variability in phosphorus content $(21.27 \%)$ and $\mathrm{Ca}: \mathrm{P}$ ratio $(25.65 \%)$ in fresh biomass was observed. The lowest coefficient of variation was found for crude fibre $(5.43 \%)$, crude ash $(7.81 \%)$ and crude protein content $(9.00 \%)$. The variability of parameters in technical maturity was found low and ranges from $2.34 \%$ for crude protein to 9.27 for phosphorus. The green mass yield is positively correlated with the calcium content $(\mathrm{r}=0.581)$, phosphorus $(\mathrm{r}=$ $0.316)$ and crude ash $(\mathrm{r}=0.077)$ and the seed yield positive correlated with calcium content $(r=0.79)$. The relationships found between qualitative indicators could be used in the breeding programs of peas.
\end{abstract}

Keywords: Pisum sativum, Genotype, Quality indicators, Correlation, Productivity.

\section{Introduction}

Peas are a culture that has long cultivated and is of growing importance for agricultural production worldwide. The need for proteinrich raw materials for human food or farm animals has led to greater interest in these plants. As a legume crop it plays an important role as a source of vegetable protein in solving the protein problem of livestock production (Zolotaryova, 2012). The protein deficiency in the ration of animals in many regions of the world is significant and its shortage is sharp, even when the protein content in the grain is balanced. Global experience shows that the most reasonable direction to solve this problem is the widespread use of grain legumes, including peas (Shpakov, 2001; Ghanbari-Bjnjar \& Lee, 2002; Okuwasola \& Ayobore, 2004).

The value of peas is determined primarily by the rich content of high-quality protein in the seeds. Depending on the varietal 


\section{Vasileva \& Kosev / Basrah J. Agric. Sci., 34(1), 195-203, 2021}

characteristics and the conditions of cultivation, in ripe seeds the protein content is from 18 to $35 \%$ and in the green mass from 14 to $24 \%$ (Chekalin, 2003).

The selection of peas is mainly oriented on the productivity of green mass and grain, the duration of the vegetation period, resistance to lodging and protein content.

The systematization of the information for the assessment of the pea samples from the available collection on quantitative signs together with their chemical characterization creates opportunities for increasing the effectiveness of the breeding programmes (Angelova \& Stoilova, 2009; Sabeva, 2019).

The purpose of the study is a comparative biochemical characteristic of plant material from peas to be done and to determine the relationships between qualitative indicators.

\section{Materials \& Methods}

The study was conducted in 2014-2016 in the experimental field of the Institute of Forage Crops, Pleven, Bulgaria $\left(43.41^{\circ} \mathrm{N}, 24.61^{\circ} \mathrm{E}\right)$. The plant material from the aboveground biomass of seven varieties have been studied (specimens of the Institute's available collection) of forage peas of different origins X07P54, X06PWY, NDPO80138-B-2, CA1P, L020140, Wt6803 and Mir (standard). A field trial was carried out in the optimal time frame according to the technology of cultivation of culture. Sowing was carried out manually according to the technology of cultivation of grass pea in three replications, between row spacing of $50 \mathrm{~cm}$ and depth of sowing of $5 \mathrm{~cm}$. Green mass yield $\left(\mathrm{kg} \cdot \mathrm{da}^{-1}\right)$, seed yield $(\mathrm{kg} / \mathrm{da})$ and duration of vegetation period (days) were measured.

Samples for biochemical analysis were taken over two phenological stages of plant development - beginning of flowering and technological maturity of the seeds. They were dried at $60{ }^{\circ} \mathrm{C}$ to constant weight. All dried samples were milled to pass through $1 \mathrm{~mm}$ screen and analysed. Crude protein content (CP) as percentage of absolute dry matter (\%, DM) was determined according to Kjeldahl method $(\mathrm{CP}=\mathrm{N} \times 6.25)$, crude fibre $(\mathrm{CF})(\%$, $\mathrm{DM})$ and crude ash (Ash) (\%, DM) by Weende methods (AOAC, 1990), macro elements calcium (Ca) (\%, DM) complexometrically and phosphorus (P) (\%, DM) by hydroquinone (AOAC, 1990).

\section{Statistical analysis}

The dependencies between the indicators were determined by correlation analysis and the variability by the coefficient of variation (VC \%) (Dimova \& Marinkov, 1999). Statistical processing (dispersion analysis) of experimental data was performed through the Microsoft Excel 2002 and Statgraphics plus 2.1 for Windows Excel programs.

\section{Results \& Discussion}

The study period covers three consecutive years differing in climatic terms. Table (1) presents the data on average monthly temperatures and the amount of precipitated rainfall by months during vegetation. The vegetation 2014 is the most favorable with average monthly air temperatures for April $12.3{ }^{\circ} \mathrm{C}$, May $16.7^{\circ} \mathrm{C}$ and June $20.6{ }^{\circ} \mathrm{C}$, and rainfall $139.8 \mathrm{~mm}, 83.0 \mathrm{~mm}$ and $54.3 \mathrm{~mm}$, respectively. As a result of the balanced combination of air temperature and optimum rainfall it has been favorable for plant development. The second- year (2015) has relatively higher temperatures in May of 18.8 ${ }^{\circ} \mathrm{C}$ and uneven precipitation distribution, characterized by a certain drought in April (43.6 mm) and May (30.6 mm), and a larger quantity in June $(95.7 \mathrm{~mm})$. The third year (2016) occupies an intermediate position over the other two years with temperatures in the 
months of April and May, close to normal (15.3-16.4 ${ }^{\circ} \mathrm{C}$ ) and rainfall between 73.1 and $76.5 \mathrm{~mm}$.

The summarized data from the three consecutive years of study were used for the variance analysis (Table 2). The results obtained at the beginning of the flowering show that for all parameters the environment factor (year) has a significant impact on their manifestation. Much less is the part in the overall variability of the genotype (variety) factor. The significant differences in crude protein, crude fibre and crude ash content give reason to believe that varieties differ in their genetic nature.

In the technical maturity stage the impact of the environment is also decisive for the crude protein, crude fibre and crude ash content. The influence of the genotype factor is almost equal to that of the environment for the calcium and phosphorus content. The influence of the genotype on the crude ash content is very low and statistically insignificant.

Table (1): Climatic characterization of experimental period.

\begin{tabular}{lccccccccc} 
Months & \multicolumn{3}{c}{$\mathbf{2 0 1 4}$} & & \multicolumn{3}{c}{$\mathbf{2 0 1 5}$} & \multicolumn{3}{c}{$\mathbf{2 0 1 6}$} \\
& Tem & Rainfall & Humidity & Tem & Rainfall & humidity & Tem & Rainfall & Humidity \\
& ${ }^{\circ} \mathrm{C}$ & $\mathrm{mm}$ & $\%$ & ${ }^{\circ} \mathrm{C}$ & $\mathrm{mm}$ & $\%$ & ${ }^{\circ} \mathrm{C}$ & $\mathrm{mm}$ & $\%$ \\
January & 0.8 & 41.8 & 82.0 & 1.9 & 12.4 & 80.0 & -0.5 & 98.0 & 78.0 \\
February & 2.3 & 3.4 & 82.0 & 2.3 & 39.2 & 80.0 & 8.7 & 46.0 & 75.0 \\
March & 9.7 & 76.9 & 68.0 & 6.7 & 68.4 & 71.0 & 8.5 & 76.6 & 73.0 \\
April & 12.3 & 139.8 & 76.0 & 12.2 & 43.6 & 54.0 & 15.3 & 73.1 & 66.0 \\
May & 16.7 & 83.0 & 70.0 & 18.8 & 30.6 & 66.0 & 16.4 & 76.5 & 71.0 \\
June & 20.6 & 54.3 & 67.0 & 20.7 & 95.7 & 64.0 & 23.0 & 45.8 & 67.0 \\
July & 23.1 & 71.8 & 67.0 & 25.8 & 21.5 & 54.0 & 24.6 & 7.8 & 57.0
\end{tabular}

Significant variation was observed (Table 2) in the phosphorus content $(21.27 \%)$ in the fresh biomass of plants and the $\mathrm{Ca}: \mathrm{P}$ ratio (25.65\%) depending on the meteorological conditions. For certain parameters such as crude fibre content (5.43\%), crude ash $(7.81 \%)$ and crude protein $(9.00 \%)$ the variation is negligible, while the calcium content is at the limit of the average level reaching $11.73 \%$. The content of the parameters in technical maturity is characterised by a very low variation of $2.34 \%$ in the crude protein content up to $9.27 \%$ for the phosphorus content.

The strongest is the variation in the $\mathrm{Ca}$ : $\mathrm{P}$ ratio $(13.02 \%)$. The data obtained from the chemical analysis carried out on the test results are shown in table (3). The pea protein is characterised by high biological value because it contains all the essential amino acids at a very favorable ratio. The crude protein content of tested plant material during flowering varies between $17.28 \%$ (X06PWY) and $22.33 \%$ (NDPO80138-B-2). In general, 
Vasileva \& Kosev / Basrah J. Agric. Sci., 34(1), 195-203, 2021

the spring samples exceed the wintering of this indicator.

As regards the crude fibre content, such a finding cannot be made. The results showed that the fresh biomass of CA1P (27.39\%), followed by NDPO80138-B-2 (25.94\%), X07P54 (25.76\%) and L020140 (25.34\%) had the highest crude fibre content and there were no significant differences between them. According to the obtained data, the samples are very similar in calcium and phosphorus content. On average, the calcium content is in the range from $1.14 \%$ (CA1P) to $1.36 \%$ (L020140), and phosphorus from $0.35 \%$ (X06PWY) to 0.435 (Wt6803). The lowest crude ash content is observed CA1P (7.93\%), L020140 (8.71\%) and Wt6803 (9.04\%).

Higher crude protein content in seeds (in technical maturity) was found in the spring samples NDPO80138-B-2 (21.59\%), X06PWY (19.95\%) X07P54 (19.78\%) and CA1P (19.60\%). From wintering only Wt6803 $(19.11 \%)$ approach them as superiority is not significant.

Table (2): Analysis of variance (ANOVA) of quality parameters of pea varieties

\begin{tabular}{|c|c|c|c|c|c|c|c|}
\hline \multirow{2}{*}{ Source } & \multirow{2}{*}{$\mathrm{df}$} & \multicolumn{6}{|c|}{ Mean square(MS) } \\
\hline & & $\mathrm{CP}$ & $\mathrm{CF}$ & $\mathrm{Ca}$ & $\mathrm{P}$ & Ash & Ca:P \\
\hline & & \multicolumn{6}{|c|}{ beginning of flowering } \\
\hline Year & 2 & $51.1056^{* *}$ & $32.8084 * *$ & $0.3100 * *$ & $0.0665 * *$ & $8.6669 * *$ & $2.9656^{\mathrm{ns}}$ \\
\hline Genotype & 6 & $13.0269 *$ & $8.9581 * *$ & $0.0173^{\mathrm{ns}}$ & $0.0023^{\mathrm{ns}}$ & $1.6925^{*}$ & $0.3287^{\mathrm{ns}}$ \\
\hline \multirow[t]{2}{*}{$\mathrm{CV}(\%)$} & & 9 & 5.43 & 11.73 & 21.27 & 7.81 & 25.65 \\
\hline & & \multicolumn{6}{|c|}{ technical maturity } \\
\hline Year & 2 & $65.6320 * *$ & $26.8842 * *$ & $0.2143 * *$ & $0.0283 * *$ & $4.2693 * *$ & $9.4418 * *$ \\
\hline Genotype & 6 & $9.7361 *$ & $2.2250 * *$ & $0.2069 * *$ & $0.0195 * *$ & $0.2613^{\mathrm{ns}}$ & $4.1095 * *$ \\
\hline $\mathrm{CV}(\%)$ & & 9.29 & 2.34 & 6.06 & 9.27 & 5.43 & 13.02 \\
\hline Error & 12 & & & & & & \\
\hline
\end{tabular}

A similar situation is in terms of crude fibre content. In the spring genotypes, it ranges from $20.57 \%$ (X07P54) to $22.53 \%$ (CA1P), and in X06PWY and NDPO80138B-2 e $21.36 \%-21.38 \%$. In the standard for wintering varieties, this indicator does not exceed $21.18 \%$. The comparative analysis of the calcium content in the seed showed a stable advantage of CA1P (2.09\%) and X07P54 (1.96\%) to all other specimens of the group. In winter varieties, the values of this parameter varied from $1.50 \%$ (Wt6803) to $1.66 \%$ (L020140 and Mir).

On average for the study period, the highest phosphorus content was observed in Wt6803 $(0.54 \%)$ and CA1P $(0.50 \%)$. The other samples (in both subspecies of peas) show almost the same value of this indicator.

The crude ash content in the seeds of the tested peas has shown that there is definite 
Vasileva \& Kosev / Basrah J. Agric. Sci., 34(1), 195-203, 2021

uniformity between them and its value ranges

(Wt6803).

from $7.51 \%$ (NDPO80138-B-2) to $8.42 \%$

Table (3): Biochemical assessment of pea varieties (2014, 2015 and 2016).

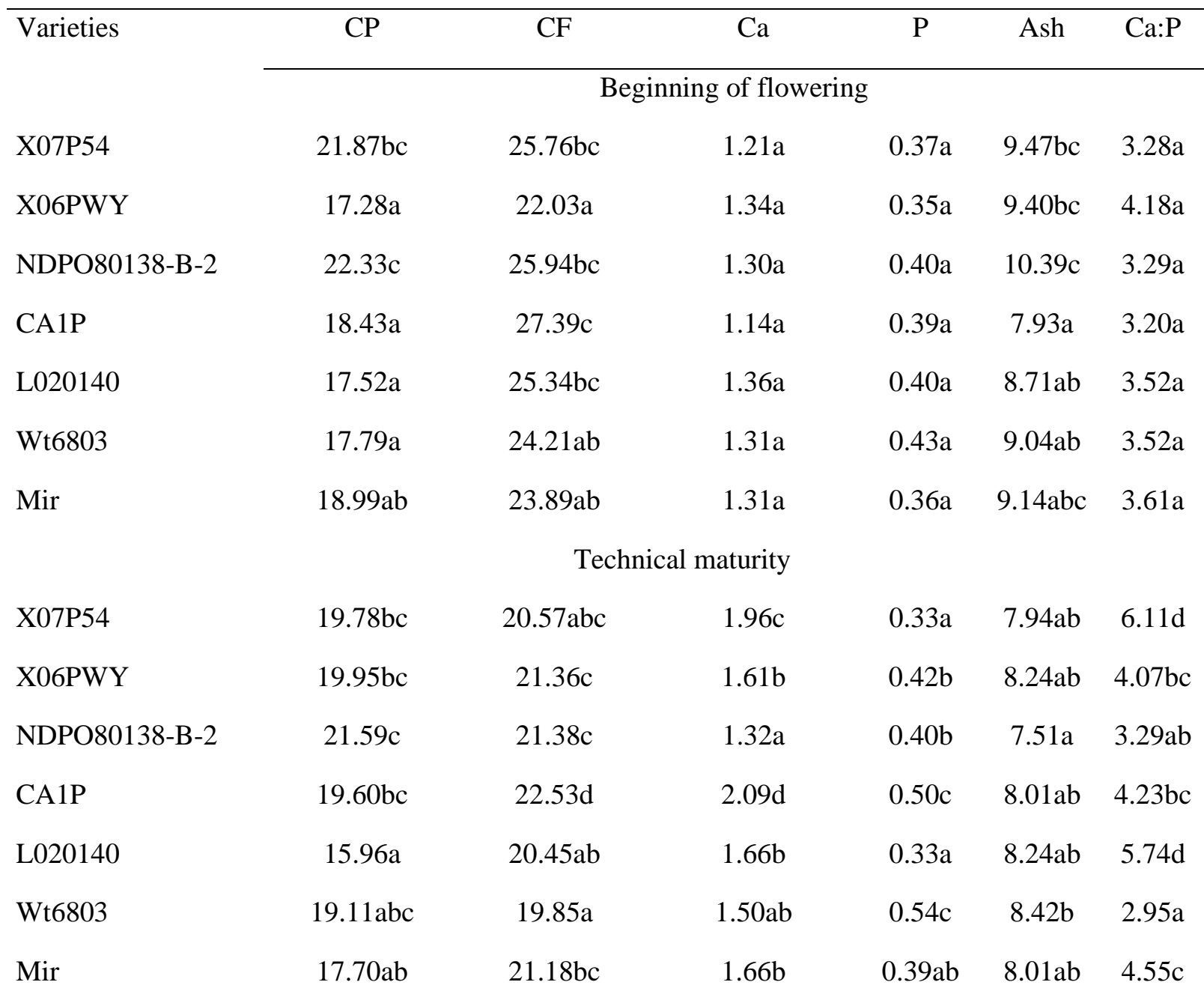

$\mathrm{CP}$ - Crude protein, $\mathrm{CF}$ - Crude fibre, $\mathrm{a}, \mathrm{b}, \mathrm{c}, \mathrm{d}$ - statistically proven differences in $\mathrm{P}=0.05$

\section{Correlation analysis}

It has been found that among the studied peas collection (Table 4) there is a negative correlation between the crude fibre content and the Ca: $\mathrm{P}$ ratio $(\mathrm{r}=-0.94)$. Statistically unimportant are all the remaining correlation coefficients. It is notable that the crude fibre content is in negative interactions with almost all indicators except phosphorus $(\mathrm{r}=0.406)$.

The green biomass yield is positively correlated with the calcium content $(\mathrm{r}=$ $0.581)$, phosphorus $(\mathrm{r}=0.316)$ and crude ash $(\mathrm{r}=0.077)$ and in negative with the crude protein content $(r=-0.38)$ and crude fibre $(r$ $=-0.49$ ).

In the technical maturity stage in the examination of the relationships between crude protein content and crude fibre content $(\mathrm{r}=0.343)$ and phosphorus $(\mathrm{r}=0.296) \mathrm{a}$ negligible positive correlation was established and between the crude protein content and between the content of crude ash $(r=-0.573)$ and calcium $(\mathrm{r}=-0.166)$ a negative (Table 5). The strongest negative and statistically significant was the correlation between phosphorus content and the Ca: $\mathrm{P}$ ratio $(\mathrm{r}=-$ $0.573)$. 
Table (4): Correlations between investigated parameters at the beginning of flowering stage.

\begin{tabular}{rrcccccc}
\hline parameters & & $\mathrm{CP}$ & $\mathrm{CF}$ & $\mathrm{Ca}$ & $\mathrm{P}$ & Ash & $\mathrm{Ca}: \mathrm{P}$ \\
\cline { 3 - 6 } $\mathrm{CF}$ & 0.444 & & & & & \\
$\mathrm{Ca}$ & -0.322 & -0.710 & & & & \\
$\mathrm{P}$ & -0.038 & 0.406 & 0.026 & & & \\
$\mathrm{Ash}$ & 0.648 & -0.295 & 0.423 & -0.099 & & \\
$\mathrm{Ca}: \mathrm{P}$ & -0.581 & $-0.940 * *$ & 0.640 & $0-.489$ & 0.129 & \\
Green mass yield & -0.380 & -0.490 & 0.581 & 0.316 & 0.077 & 0.292 \\
\hline
\end{tabular}

Table (5): Correlations between investigated parameters at the maturity stage.

\begin{tabular}{rccccc}
\hline parameters & $\mathrm{CP}$ & $\mathrm{CF}$ & $\mathrm{Ca}$ & $\mathrm{P}$ & Ash \\
\cline { 2 - 5 } $\mathrm{CF}$ & 0.343 & & & \\
$\mathrm{Ca}$ & -0.166 & 0.411 & & \\
$\mathrm{P}$ & 0.296 & 0.148 & -0.034 & & \\
$\mathrm{Ash}$ & -0.573 & -0.455 & 0.139 & & \\
$\mathrm{Ca}: \mathrm{P}$ & -0.506 & -0.097 & 0.576 & $-0.793^{*}$ & 0.033 \\
\hline
\end{tabular}

Between the seed yield and the phosphorus content $(\mathrm{r}=-0.35)$, crude protein $(\mathrm{r}=-0.18)$ and crude fibre $(\mathrm{r}=-0.03)$ the correlation is negative, but weak and insignificant, while with the calcium content is positive and statistically significant $(\mathrm{r}=0.79)$ (Fig. 1). Therefore, in order to successfully carry out the selection work associated with increasing crude protein and crude fibre content, it is good to prefer forms combining increased content of these parameters with those which are not very high productive of grain.

The duration of the vegetation period correlates positively with the phosphorus content $(\mathrm{r}=0.08)$ and with crude ash content $(\mathrm{g}=0.54)$.

The results obtained for the protein content of the ripe pea seeds are consistent with the results of most of the authors. Červenski et al. (2017) reported that in their sample the pea protein content of the seeds ranged from $15.8 \%$ to $34.7 \%$ of the dry matter.

Other authors (Mikić et al., 2007) believed that wintering pea genotypes have significant potential both for tolerance to low temperatures and for high and stable grain yields.

Angelova \& Sabeva (2013) in analysing pea samples report the presence of a weak 
negative correlation only between the crude protein and crude fibre content. The authors report that on the grouping of varieties of peas in crude protein there is no established correlation between the morphological signs of seeds, the 1000 seeds weight and their phenotype.

According to Suchkova (2009), which in her research has used genotypes of peas with different morphotypes the type of leaves has no determining role in the relationships between qualitative indicators. The calculated value of the correlation coefficient between the crude protein and crude fibre content, both in mustache and leaf forms, has been strongly negative.

Kadermas (2014) and Maksimenia (2016) consider that success in the selection depends to the greatest extent on the richness of the source material, possessing useful economic signs and properties.

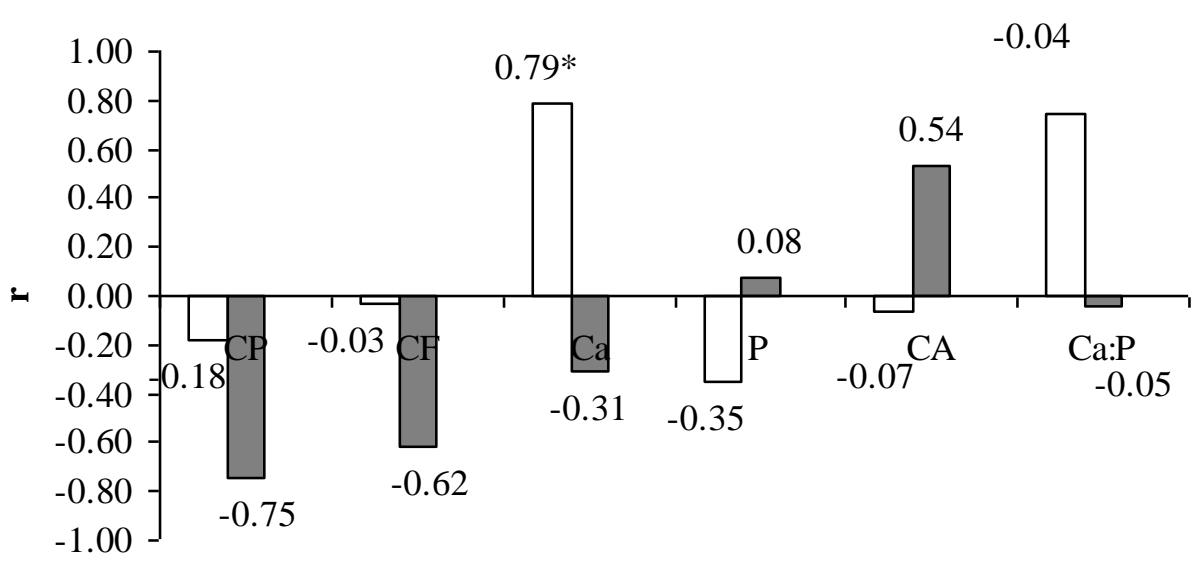

$\square \mathrm{A} \square \mathrm{B} \square$

Fig. (1). Correlations of studied parameters with seed yield and duration of vegetation period.

$\mathrm{CP}$ - Crude protein, $\mathrm{CF}$ - Crude fibre, $\mathrm{A}$ - seed yield $(\mathrm{kg} / \mathrm{da}), \mathrm{B}-$ vegetation period (days)* $\mathrm{p} \leq 0.05$

\section{Conclusions}

The chemical assessment of the fresh biomass and seeds of the pea samples by the crude protein, crude fibre, calcium, phosphorus and crude ash content gives the possibility to make the following important conclusions: At the beginning of flowering stage the NDPO80138B-2 and X07P54 were reported high levels for crude protein $(22.33 \%, 21.87 \%)$, crude fibre $(25.94 \%, 25.76 \%)$ and crude ash $(10.39 \%$, $9.47 \%$ ). In technical maturity with high content of crude protein and crude fibre are distinguished NDPO80138-B-2 (21.59\%,
21.38\%), X06PWY (19.95\%, 21.36\%), X07P54 (19.78\%, 20.57\%) and CA1P $(19.60 \%, 22.53 \%)$, by calcium content CA1P (2.09\%), and by phosphorus Wt6803 (0.54\%). More significant variability in phosphorus content $(21.27 \%)$ and $\mathrm{Ca}: \mathrm{P}$ ratio $(25.65 \%)$ in fresh biomass was observed. The lowest coefficient of variation was found for crude fibre content $(5.43 \%)$, crude ash $(7.81 \%)$ and crude protein $(9.00 \%)$.

The variability of parameters in technical maturity is low and ranges from $2.34 \%$ for crude protein content to $9.27 \%$ for phosphorus 


\section{Vasileva \& Kosev / Basrah J. Agric. Sci., 34(1), 195-203, 2021}

content. The green mass yield is positively correlated with the calcium content $(\mathrm{r}=$ $0.581)$, phosphorus $(\mathrm{r}=0.316)$ and crude ash $(\mathrm{r}=0.077)$, and in a negative with the crude protein content $(\mathrm{r}=-0.38)$ and crude fibre $(\mathrm{r}=$ - 0.49). Between the seed yield and phosphorus content $(\mathrm{r}=-0.35)$, crude protein $(\mathrm{r}=-0.18)$ and crude fibre $(\mathrm{r}=-0.03)$ the correlation is negative and with the calcium content is positive $(r=0.79)$.

\section{Conflicts of interest}

The authors declare that they have no conflict of interests.

\section{ORCID:}

\section{M. Vasileva: 0000-0001-5602-7892}

V. I. Kosev: http://orcid.org/0000-0002-66199409

\section{References}

Angelova, S., \& Sabeva, M. (2013). Chemical characterization of pea in Bulgarian collection. Rastenievadni nauki, 50, 37-40. (In Bulgarian). https://cropscience-

bg.org/page/bg/details.php?article_id=208\&tab=en

Angelova, S., \& Stoilova, Tz. (2009). Maintenance, enrichment and preservation of grain legume collections in Bulgaria. Proceeding of the Fourth Balkan Symposium on Vegetable and Potatoes vol 2, ISHS, Acta Horticulture 830, 695-701.

AOAC (1990). Offical methods of analysis. Association of the official analytical chemists. $15^{\text {th }}$ edition, Arlington,

771. https://www.worldcat.org/title/official-methods-ofanalysis-of-the-association-of-official-analyticalchemists/oclc/20709424

Červenski, J., Danojević, D., \& Savić, A. (2017). Chemical composition of selected winter green pea (Pisum sativum L.) genotypes. Journal of the Serbian Chemical Society, 82, 12371246.http://www.doiserbia.nb.rs/img/doi/03525139/2017/0352-51391700094C.pdf

Chekalin N. M. (2003). Genetic basis for the selection of legumes for resistance to pathogens. Poltava: Intergrafsha, $186 \mathrm{pp}$.
Dimova, D., \& Marinkov, E. (1999). Experimental work and biometrics. HAI-Plovdiv, 263pp. (In Bulgarian).

Ghanbari-Bjnjar, A., \& Lee, H. C. (2002). Intercropped field beans (Vicia faba) and wheat (Triticum aestivum) for whole crop forage: effect of nitrogen on forage yield and quality. The Journal of Agricultural Science, 138, 311-315. https://doi.org/10.1017/S0021859602002149

Kadermas, I. G. (2014). Formation of photosynthetic and symbiotic apparatuses of plants and their contribution to the increase in the productivity of pea sowing agrocenoses (Pisum sativum L.). Ph. D. Thesis, Agrarian University of Omsk, Omsk, 147 pp.

https://omgpu.ru/sites/default/files/files/dissert/4271 /kadermas_dissertaciya.pdf

Maksimenia, E. V. (2016). Correlations between economically valuable signs of vegetable pea. Bulletin of the Belarussian State Agricultural Academy, 1, 32-35. http://elc.baa.by/vestnik20161/vestnik2016-1.pdf

Mikić, A., Mihailović, V., Duc, G., Ćupina, B., Étévé, G., Lejeune-Hénaut, I., \& Mikić, V. (2007). Evaluation of winter protein pea cultivars in the conditions of Serbia. Zbornik radova Instituta za ratarstvo i povrtarstvo 44, 107. (In Serbian)

Okuwasola A. J., \& Ayobore A. V. (2004). Chemical characterization and protein quality evaluation of leaf protein concentrates from Glyricidia sepium and Leucaena leucocephala. International Journal of Food Science and Technology, 39, 253-261.

https://doi.org/10.1111/j.1365-2621.2004.00779.x

Shpakov, A. S. (2001). The main directions of increasing the production of feed protein in Russia. Fodder Production, 3, 6-9. https://www.elibrary.ru/item.asp?id=22435883

Suchkova, T. N. (2009). Physiological-biochemical peculiarities of carbohydrates and proteins accumulation in seeds of varieties and pea lines (Pisum sativum L.). Ph. D. Thesis, University of Voronezh, Voronezh. (English Abstract). http://www.aspirant.vsu.ru/pdf/autoreferats/1407.pd $\mathrm{f}$

Zolotaryova, S. V. (2012). Evaluation and creation of the initial material for the selection of vegetable pea in the central region of the nonchernozem zone of

https://agromage.com/book.php?id=3 
Russia. Ph. D. Thesis, University Russia, Moscow, 27pp. (English Abstract). http://vniioh.ru/ocenka-i-sozdanie-isxodnogo-materialadlya-selekcii-goroxa-ovoshhnogo-v-centralnomrajone-nechernozyomnoj-zony-rossii

\section{Pisum sativum L. التقييم الكيموحيوي لأصناف البازلاء فيليانا فاسيليفا و فالنتين كوسيف \\ معهد المحاصيل العلفية، 89 شارع "الجنرال فلاديمير فازوف"، 5800 بلفن، بلغاريا}

المستخلص: تمت دراسة سبعة اصناف مختلفة من البازلاء X07P54 Pisum sativum L. و و X06PWY NDPO80138-B-2 و CA1P و L020140 و Wt6803 و Mir. اجري التقييم الكيموحيوي للكتلة الحيوية فوق سطح التربة وبذور اصناف البازلاء • في بداية مرحلة التزهير سجل الصنفان NDPO80138-B-2 و X07P54 مستويات عالية للبروتين الخام (22.33\% و 21.87\%) والألياف الخام (25.94\% و 25.76٪) والرماد الخام (10.39٪ و و

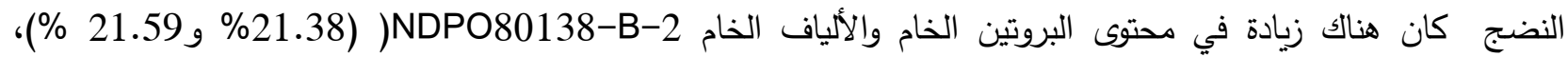

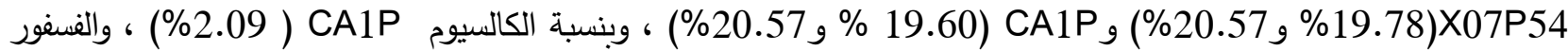

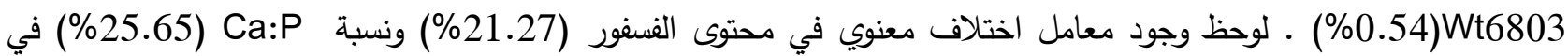
الكتلة الحيوية الرطبة ،واقل معامل اختلاف وجد في الألياف الخام (5.43\%) والرماد الخام (7.81\%) والبروتين الخام (9.00\%) .اختلاف الصفات في مرحلة النضج كانت اقل وتراوحت من 2.34\% للبروتين الخام الى 9.27\% للفنفر كان الارتباط موجبا بين الحاصل الاخضر ومحتوى الكالسيوم(r=0.581) ) ، الفنفور (r=0.581 ) والرماد الخام (r=0.077) ، وارتباطا موجبا لحاصل البذور مع محتوى الكالسيوم (r=0.79) .ويمكن استعمال العلاقات الموجودة بين المؤشرات النوعية في برامج تربية البازلاء. 